\title{
PHENOLIC COMPOUNDS AS A MARKER FOR DIFFERENT BOTANICAL AND GEOGRAPHICAL ORIGINS OF HONEYS
}

\author{
ABDEL AZIEM, M. A. I. \\ Bee Research Dept., Plant Protection Research Institute, ARC, Dokki, Giza
}

(Manuscript received 10 July 2014)

\begin{abstract}
The objective of this study was the determination of 18 phenolic compounds in different botanical regions, Authentic samples of clover, cotton and citrus honeys were collected from different districts of Egypt, honey samples of two new regions (Siwa, Mathrouh governorate) and (Bir el abed, North Sinia governorate), which their botanical origin were assured then they were analyzed to asssay flavonoids and phenolic acids content by using HPLC device. Results showed their were 18 phenolic compounds found in citrus and clover honey samples, while 20 phenolic constituents were in cotton honey samples. On the other hand, there were 4 and 8 phenolic compounds found in Ber el abed and Siwa honey samples, respectivly, The highest amount of phenolic compounds in the main Egyptain honeys was in cotton honey, caffeic acid was the dominant compound in both citrus and clover honeys, but galangin in ber el abed honey sample and gallic acid in Siwa honey samples. It is cleared that there were varation in phenolic compounds between honey samples, it may be due to in difference in botincail orgain ( plant source).

Key words: authentic honey, flavonoids, Honey, phenolic acids.
\end{abstract}

\section{INRODUCTION}

Honey is the substance made when the nectar and sweet deposits collected, modified and stored in the honeycomb by honeybees. The definition of honey stipulates a pure product that does not allow for the addition of any other substance(Fox and Cameron,1995), Honey is a source of flavonoids and phenolic acids in human diet. Flavonoids are polyphenols plant pigments that are synthesized from phenyl alanine, generally display marvelous colour known from flower petals, mostly emit fluorescence when they are excited by UV light, and are ubiquitous to green plant cell. The flavonoids are used by botanists for taxonomical classification(Harvsteen, 2002). Honeys have a rich phenolic profile consisting of benzoic acids and there esters, cinnamic acids and their esters, and flavonoid aglycones. Flavonoids in honey may originate from nectar, pollen or propolis. Citrus nectar and pollen contain hesperidin, which is transformed into hespertin by the bee. Hespertin is the characteristic flavanone of citrus honey (Solner et al., 1995) .Traditionally, the floral source of honey has been identified by sensory and pollen analysis of honey. However, the use of phenolic compounds in the identification of 
honey has been suggestedand has since been used as a tool for studying the floral and geographical origins of honeys.(Martos et al., 2000) mentioned that European Eucalyptus honeys showed a common and characteristic profile in which the flavonoids myricetin, tricetin, quercetin, luteolin and kaempferol were identified. Their contents, and relative amounts, in the analyzed honey samples were quite constant and supported their floral origin. Myricetin, tricetin, and luteolin had not been identified as floral markers in any other honey sample previously analyzed in their laboratory (chestnut, citrus, rosemary, lavender, acacia, rapeseed, sunflower, heather, lime tree, etc.) or reported in the literature, suggesting that these could be useful markers. Only in some individual heather samples produced in Portugal has tricetin previously been detected in minor amounts. The relationship between phenolic content and antioxidant power was discussed. Comparative experimental analysis was performed with an artificial honey and processed honeys. Raw Millefiori honey is rich in both amount and variety of antioxidant substances, and its inclusion in the diet may be recommended to complement other polyphenol sources.

This study aimed to determine the flavonoid and phenolic acid contents of clover, cotton and citrus floral honeys which are the main botanical sources of honey in Egypt.

\section{MATERIALS AND METHODS}

The present investigation was carried out at the Beekeeping Research Dept., Plant Protection Research Institute, Giza, during years 2012 and 2013, to study the phenolic coumpounds of the Egyptian honeys which collected from different sources and different regions.

The analyses of phenolic components in three main Egyptian honeys (citrus, clover and cotton) and honey collected from two new regions (Siwa, Mathrouh governorate) and (Bir el Abed, North Sinia governorate)to study their potential for floral authentication. The analyses included 21 standard flavones (dadzin, b-oH benzoic, caffeic, gallic, kaempherol, pyro gallic, ferulic, salicylic, vanillin, genstin, pcoumaric, quercetin, chrysin, galangin, phenol, Cinnamic, Dadazien, 3, 5 di methoxy benzyl, genstein, catechine and Pinostrobin). These components were separated by High Performance Liquid Chromatography (HPLC) from 15 honey samples, 3 samples of each honey type.

Preparing of $10 \%$ honey solution, one $\mathrm{g}$ of honey was dissolved in $10 \mathrm{ml}$ ethyl alcohol $70 \%$, and then kept in closed glass tubes for analysis. Estimation weight \% of phenolic compounds, The scanning of identified phenolic compounds extracted in 
honey samples by (HPLC) analysis are estimation of weight \% for these compound was calculated

As follows:

Weight \% phenolic $=100 \times\left(\mathrm{PH} / \mathrm{PH}^{*}\right) \times\left(\mathrm{v} / \mathrm{v}^{*}\right) \times\left(\mathrm{w}^{*} \mathrm{x} \mathrm{w}\right)$

Were: $\mathrm{PH}$ : area for sample, $\mathrm{PH}^{*}$ : area of standard, $\mathrm{V}$ : volume of sample, $\mathrm{V}^{*}$ : volume of standard, $\mathrm{W}^{*}$ : weight of standard, W: Weight of sample

HPLC Identification: identification of phenolic compounds of the honey samples was performed by a JASCO, using a hypersil C18 reversed- phase column $(250 \times 4.66 \mathrm{~mm})$ with $5 \mu \mathrm{m}$ particle size.Injection by means of a Rheodyne injection valve with $50 \mu$ fixed loop was used. A constant flow rate of $1 \mathrm{ml} \mathrm{min}^{-} 1$ was used with two mobile phases (A) $0.5 \%$ acetic acid in distilled water at $\mathrm{pH} 2.65$; and solvent (B) $0.5 \%$ acetic acid in $99.5 \%$ acetonitcile. The elution gradient was linear starting with (A) and ending with (B) over 35 min, using a $\mu \mathrm{v}$ detector set at wavelength 254 $\mathrm{nm}$. Phenolic compounds of each sample were identified by comparing their relative retention times with those of the standards mixture chromatogram. The concentration of individual compound was calculated on the basis of the peak area measurements, and then converted to $\mu \mathrm{g}$ phenolic $\mathrm{g}^{-} 1 \mathrm{dry}$ weight. All chemicals and solvents used were in HPLC spectral grade. Twenty standard phenolic compounds (Listed in Table 6) were obtained from Sigma (St, Louis , USA) and from Merck-Schuchard (Munich, Germany) chemical companies (Soliman, 2002).

\section{Statistical analysis}

A descriptive analysis of the variables was carried out and the normality of the data was also verified by means of the Kolmogorov test.An analysis of variance was made (one way ANOVA) to detect if the factor origin was significant, namely, if the means of the variables considered were different depending on the type of honey and carry out a study of the bivariate correlations between all the variables, detecting which of them were significant. Analysis was made on the variables of the study with the aim of determining which of them discriminated best between them the honey varieties analysed, as well as establishing a mathematical model for this purpose, statistical package for Social Science (SPSS) was used for these objectives(ward linkage method).

\section{RESULTS AND DISCUSSION}

The phenolic contents of the 15 Honey samples were analysed, and the results were tabulated in Table (1). 18 phenolic compounds were found in citrus honey samples, 18 phenolic were found in clover honey samples, while 20 phenolic 
constituents were found in cotton honey samples. On other hand there were 4 and 8 found in ber el abed and siwa honey samples, respectivly.

The highest amount of phenolic compounds in the main Egyptain honeys was detected in cotton honey $(220.5 \mathrm{ng} / 100 \mathrm{~g})$. However, citrus, (124.18 ng/100g) and clover, (120.54ng/100g) honeys, in addation it was (32.43 ng/100g) in Ber el Abed honey and $(167.4 \mathrm{ng} / 100 \mathrm{~g})$ in Siwa honey sample of total separated phenolic constituents.

It is obvious from data in Tables (1) that, caffeic acid was the dominant compound in both citrus and clover honeys. It was represented by $42.33 \%$ and $52.33 \%$ of the total phenolic acids and p-coumaric was dominated compound in cotton honey, galangin flavonid in Ber el Abed honey sample and gallic acid in siwa honey sample and it is cleared that there were in phenolic compounds between honey samples, it may be due to the difference in the botincail orgain ( plant source).

Phenolic compounds are a widespread group of antioxidants present in plants and their derived products. Some of these compounds are taken over from plants to honey by bees (Apis mellifera).Few phenolic compounds were used as the honey authenticity indicators. Discrimination of honeydew honeys and flower honeys is possible due to the difference in the concentration of protocatechuic acid (Kreutzmannetal., 2008) Comparing of hydroxybenzoic and cinnamic acid hydroxyderivatives concentration can be used to differentiate variouskinds of monofloral honeys.Useful markers of heather honey could be cis,trans-abscisic acid and trans,trans-abscisic acid.The major source of kaempferol and its derivatives in rosemary honey is not rosemary pollen but rosemary nectar only. Theseresults suggest that phenolic markers of the botanical origin honey should be addressed to the identification of nectar flavonoids [Ferreres et al., 1998 ]. Phenolic compounds can be useful markers for the floral origin of some honey types, particularly in heather, chestnut, eucalyptus،rapeseed and lime-tree honeys. The role of particular markers was confirmed, for example hesperetin for citrus honey, kaempferol for rosemary honey and quercetin for sunflower honey. Abscisic acid، which was indicated as a marker for heather honey, is also present in significant amounts in rapeseed, lime-tree and acacia honeysThe results of comprehensive study of phenolic acids in 49 honey samples confirm significant differences of phenolic acidscontent depending on the floral origin [Tomas-Barberanet al., 2001.[

It is very likely that some phenolic compounds could be used also as the indicator of mead quality and composition.Ferreres et al., (1996) reported that the floral source can be reliably authenticated on presence of phenolic constituents such as volatile compounds, abscissic acid, myricetin and quercetin. Also, Hausler 
andMontage, (1990) found that heather honey, (Calluna vulgarisand Erica arborea) could be distinguished from clover, lime tree and acacia honeys by their high phenylacitic acid and benzoic acid contents.Yoa, et al., (2004) analyzed the flavonoids in Australian honeys from five botinical species and suggested that those honeys of various floral species can be differentiated by their levels of total flavonoid being $2.12 \mathrm{mg} / 100 \mathrm{~g}$ for heather and $6.35 \mathrm{mg} / 100 \mathrm{~g}$ for tea tree honey.In the similar and previous work, Guyat, et al., (1999) stated that, heather honeys could be distinguished from non-heather samples on the basis of their content in benzoic acid which was present in heather honeys at concentrations ranging from 2 to $64 \mu \mathrm{g} / \mathrm{g}$, as opposed to less than $1.3 \mu \mathrm{g} / \mathrm{g}$ in the non-heather samples. Besides, Yao, et al. , (2003) found that in Australian jelly bush honey (Leptospermum polygalifolium) the content of total phenolic acids averaged $5.14 \mathrm{mg} / 100 \mathrm{~g}$ honey, with gallic acid $(23.6 \%)$ and coumaric acid $(22.2 \%)$ as the main components while caffeic acid represented $9.7 \%$ of the total phenolics.

Blasa et al. (2006) pointed that total polyphenols, flavonoids and antioxidant power of raw honey samples from two of the most common Italian varieties, i.e., Millefiori and Acacia, were evaluated. Phenolic content, expressed as caffeic acid equivalents, ranged from 12.5 to $17.5 \mathrm{mg} / 100 \mathrm{~g}$ and from 3 to $11 \mathrm{mg} / 100$ $\mathrm{g}$ in Millefiori and Acacia honeys, respectively. All Millefiori samples exhibited the highest flavonoid concentration being between 1.23 and $2.93 \mathrm{mg}$ catechin equivalents (CE)/100 g honey. Total flavonoids in $100 \mathrm{~g}$ Acacia honeys were in the range of 0.45$1.01 \mathrm{mg}$ CE. Acacia honeys had lower total antioxidant power, as assessed by ferric reducing/antioxidant power assay, than Millefiori

Statistically, it was verified that the variables were different, depending on the type of honey. The variables with the greatest discriminatory power were water activity and electrical conductivity with discrimination coefficients of -22.367 and 11.739 , respectively. The overall proportion of accurately arranged samples was $96.6 \%$. 
Table 1. The range, mean and percentages of phenolic constituents in the main Egyptian honeys, (citrus, clover and cotton) collected from different regions, (in $\mathrm{ng} / 100 \mathrm{~g}$ )

\begin{tabular}{|c|c|c|c|c|c|c|c|c|c|c|}
\hline \multirow{3}{*}{$\begin{array}{l}\text { phenolic } \\
\text { constituents }\end{array}$} & \multicolumn{10}{|c|}{ Type of honey } \\
\hline & \multicolumn{2}{|c|}{ citrus } & \multicolumn{2}{|l|}{ Clover } & \multicolumn{2}{|l|}{ cotton } & \multicolumn{2}{|c|}{ Ber el abed } & \multicolumn{2}{|l|}{ siwa } \\
\hline & mean & $\%$ & mean & $\%$ & mean & $\%$ & mean & $\%$ & mean & $\%$ \\
\hline Dadzin & 9.84 & 7.92 & 6.82 & 5.66 & 1.57 & 0.71 & 0.00 & 0.00 & 0.00 & 0.00 \\
\hline B-oh benzoic & 4.38 & 3.52 & 0.47 & 0.39 & 4.28 & 1.94 & 11.30 & 34.84 & 21.29 & 12.72 \\
\hline Caffeic & 52.56 & 42.33 & 63.07 & 52.33 & 28.45 & 12.90 & 0.00 & 0.00 & 73.19 & 43.72 \\
\hline Gallic & 0.83 & 0.67 & 5.98 & 4.96 & 10.51 & 4.77 & 0.00 & 0.00 & 48.98 & 29.25 \\
\hline Kaempherol & 0.71 & 0.57 & 0.85 & 0.71 & 1.38 & 0.63 & 0.00 & 0.00 & 0.00 & 0.00 \\
\hline Pyro gallic & 11.43 & 9.20 & 1.49 & 1.24 & 57.34 & 26.01 & 0.00 & 0.00 & 0.00 & 0.00 \\
\hline Ferulic & 1.37 & 1.10 & 1.65 & 1.37 & 2.92 & 1.32 & 0.00 & 0.00 & 0.00 & 0.00 \\
\hline Salicylic & 3.92 & 3.16 & 4.71 & 3.91 & 4.57 & 2.07 & 0.00 & 0.00 & 0.00 & 0.00 \\
\hline Vanillin & 1.25 & 1.01 & 0.74 & 0.62 & 5.29 & 2.40 & 0.00 & 0.00 & 0.00 & 0.00 \\
\hline Genstin & 10.91 & 8.78 & 2.35 & 1.95 & 3.95 & 1.79 & 0.00 & 0.00 & 0.00 & 0.00 \\
\hline P-coumaric & 2.67 & 2.14 & 3.20 & 2.65 & 68.14 & 30.90 & 0.00 & 0.00 & 2.34 & 1.40 \\
\hline Quercetin & 1.36 & 1.10 & 1.64 & 1.36 & 0.55 & 0.25 & 0.00 & 0.00 & 0.00 & 0.00 \\
\hline Chrysin & 0.004 & 0.00 & 0.01 & 0.00 & 0.01 & 0.00 & 0.00 & 0.00 & 2.84 & 1.70 \\
\hline Galangin & 0.007 & 0.01 & 0.01 & 0.01 & 0.007 & 0.00 & 11.54 & 35.58 & 11.50 & 6.87 \\
\hline Phenol & 22.26 & 17.93 & 26.72 & 22.17 & 22.45 & 10.18 & 0.10 & 0.31 & 3.16 & 1.89 \\
\hline Cinnamic & 0.0 & 0.00 & 0.0 & 0.00 & 7.95 & 3.61 & 0.00 & 0.00 & 0.00 & 0.00 \\
\hline Dadazien & 0.08 & 0.06 & 0.09 & 0.08 & 0.35 & 0.16 & 0.00 & 0.00 & 0.00 & 0.00 \\
\hline $\begin{array}{l}3,5 \text { di methoxy } \\
\text { benzyl }\end{array}$ & 0.003 & 0.00 & 0.003 & 0.00 & 0.01 & 0.00 & 9.49 & 29.26 & 0.00 & 0.00 \\
\hline Genstein & 0.0 & 0.00 & 0.0 & 0.00 & 0.42 & 0.19 & 0.00 & 0.00 & 0.00 & 0.00 \\
\hline Catechine & 0.64 & 0.49 & 0.74 & 0.61 & 0.0 & 0.00 & 0.00 & 0.00 & 4.10 & 2.45 \\
\hline Pinostrobin & 0.0 & 0.00 & 0.0 & 0.00 & 0.35 & 0.16 & 0.00 & 0.00 & 0.00 & 0.00 \\
\hline Total & 124.18 & 100.00 & 120.52 & 100.00 & 220.50 & 100.00 & 32.43 & 100.00 & 167.40 & 100.0 \\
\hline
\end{tabular}




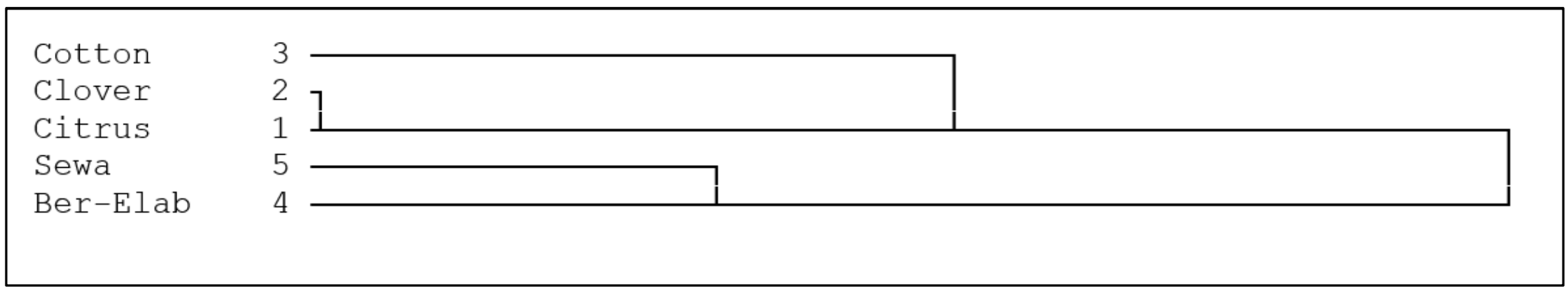

\begin{tabular}{|c|c|c|c|c|c|c|}
\hline & & $\begin{array}{l}\text { Citrus } \\
\text { V1-1 }\end{array}$ & $\begin{array}{l}\text { Clover } \\
\text { V1-2 }\end{array}$ & $\begin{array}{c}\text { Cotton } \\
\text { V1-3 }\end{array}$ & $\begin{array}{c}\text { Ber-Elab } \\
\text { V1-4 }\end{array}$ & $\begin{array}{l}\text { Sewa } \\
\text { V1-5 }\end{array}$ \\
\hline Citrus & $\mathrm{V} 1-1$ & 0 & 2.5209 & 5.3412 & 5.8123 & 6.9287 \\
\hline Clover & $\mathrm{V} 1-2$ & 2.5209 & 0 & 5.1894 & 5.5504 & 6.5356 \\
\hline Cotton & $\mathrm{V} 1-3$ & 5.3412 & 5.1894 & 0 & 6.9003 & 7.8852 \\
\hline Ber-Elab & $\mathrm{V} 1-4$ & 5.8123 & 5.5504 & 6.9003 & 0 & 4.8047 \\
\hline Sewa & V1-5 & 6.9287 & 6.5356 & 7.8852 & 4.8047 & 0 \\
\hline
\end{tabular}

Figuer 1. discrimination analysis of honey bee samples under studDendrogram obtained by hierarchical cluster analysisy. 


\section{REFERENCES}

1. Blasa, M. Candiracci, M. Accorsi, A. Piacentini, M. P. Albertini, M. C. and Piatti, E. 2006. Raw Millefiori honey is packed full of antioxidants. J. Food. Chem., 97:217-222.

2. Ferreres, F.; Andrade, P.; Gil, M. I. and Tomas-Barberan, F. A. (1996). Floral nectar phenolics as biochemical markers for the botanical origin of heather honey. Zeitschrift fur Lebensmittel Untersuchung und Forschung, 202:40-44.

3. Ferreres, F. Juan, T. Perez-Arquillue, C. Herrera-Marteache, A. GarciaViguera, C. Tomas-Barberan, F. A. 1998. Evaluation of Pollen as a Source of Kaempferol in Rosemary Honey. J Sci. Food Agric.; 77, 4; 506-510.

4. Fox, B. Cameron, A. 1995. Food science nutrition and health: Carbohydrates. 6th ed. London: Edward Arnold; p. 95-105.

5. Guyot, C. Scheirman, V. and Collin, S. 1999. Floral origin markers of heather honeys: Calluna vulgaris and Erica arborea. J. Food. Chem., 64:3-11.

6. Harvsteen, B. 2002.The biochemistry and medical significance of flavonoids. Pharmacol Therapeutics. 96 (2-3): 67-202.

7. Hausler, M. and Montag, A. 1990. Minorbestandteile des Honigs mit Aromorelevanz. III Trachtspezifische Verteitung aromatischer Aldehyde und Vorkommen von Stiekstoff und Schaefelheterocyclen. Dtsch. Lebensm. Rdsch. 86:171-174.

8. Kreutzmann, S. L. P. Christensen, M. Edelenbos, 2008 investigation of bitterness in carrots ( Daucus carota $\mathrm{L}$ ) based on quantitative chemical and sensory analysis . LWT-Food Sci. Technol. 41 :193-205.

9. Martos, I. Ferreres. F. Yao, L. D'Arcy, B. Caffin N., and Tomas, B. F. A. (2000). Flavonoids in monospecific eucalyptus honeys from Australia. J. Agric. Food. Chem., 48:4744-8.

10. Soler, C. Gil, M.I. Garcia-Viguera, C. and Tomas-Barberan FA. (1995) Flavonoid patterns of French honey with different floral origin. Apidologie. 26: 53-60.

11. Soliman, M. H. 2002. Allelopathic potential of sunflower residues in controlling wild oat assoiated with wheat .Ph.D.Thesis,Fac. of Sci.Cairo Univ.

12. Tomas-Barberan, F.A. Martos, I. Ferreres, F., Radovic, B.S. Anklam, E. 2001. HPLC flavonoid profiles as markers for the botanical origin of European unifloral honeys. J. Sci. Food Agric. 81, 485-496.

13. Yao, L. Datta, N. Tomás, B. F. A. Ferreres, F. Martos, I. and Singanusong, R. 2003. Flavonoids, phenolic acids and abscisic acid in Australian and New Zealand Leptospermum honeys .J. Food. Chem., 81:159-168.

14. Yao, L. Jiang, Y. Singanusong, R. D'Arcy, B. Datta, N. Caffin, N. and Raymont, K. 2004. Flavonoids in Australian Melaleuca, Guioa, Lophostemon, Banksia and Helianthus honeys and their potential for floral authentication. Food. Res. Int., 37:166-174. 


\section{تقدير المركبات الفينولية فى اعسال مختلفة \\ كدليل لمصدرها النباتى والجغرافى}

\section{محمد على ابر اهيم عبد العظيم}

قسم بحوث النحل - معهد بحوث وقاية النباتات- مركز البحوث الزراعية - الدقى - الجيزة

تهدف الدراسة الى مقارنة المكونات الفينولية لعدد من عينات العسل المختلفة المصدر النباتى و الجغر افى وذللك من خلال عينات عسل برسيم وموالح وقطن جمعت من مناطق زر اعة هذه المحاصيل وكذلك جمعت عينات عسل من المناطق الجديدة ممنلة فى منطقة سيوة - محافظة مطرو ح ومنطقة بئر العبد - محافظة شمال سيناء وتم استخلاص المركبات الفينولية منها وتقدير ها بواسطة جهاز التحليل الكروماتوجر افى السائل عالى الكفاءة. وقد اوضحت النتائج اختلافات فى عدد المركبات المقدرة وكميتها فى هذه العينات تحت الدراسة وبذللك يكون المصدر النباتى او المنطقة الجغر افية عامل مؤثر بدرجة كبيرة على التركيب

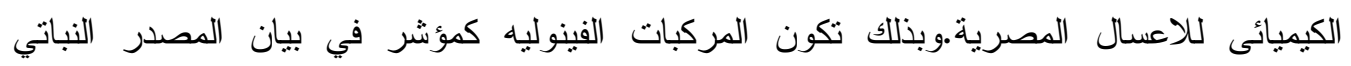
و الجغر افي للاعسال المنتجه.

وقد أوضحت النتائج وجود 11 مركب فينولى فى كل من عسل الموالح و البرسيم • بينما وجد

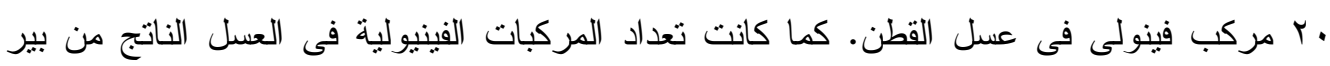

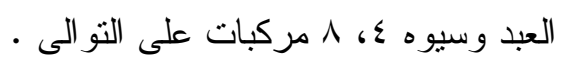

اوضحت النتائج تفوق عسل القطن المصرى على على كل الاعسال المختبرة فى كميات المركبات

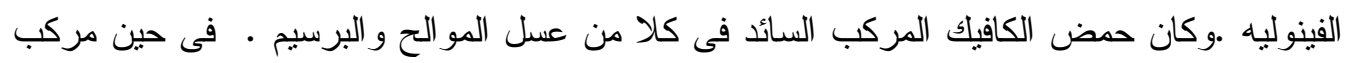

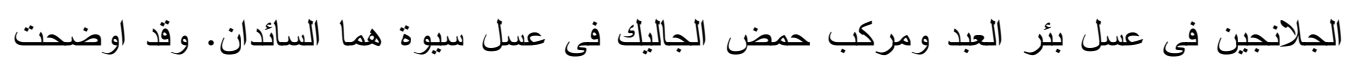

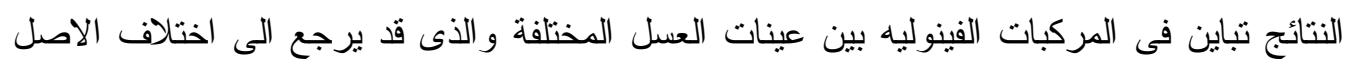
النباتى للعسل . 